\title{
BIBLIOMETRIC ANALYSIS OF THE FIELD OF GREEN PUBLIC PROCUREMENT
}

\author{
Simona Roxana Pătărlăgeanu ${ }^{1 *}$, Mihai Dinu ${ }^{2}$ and Marius Constantin ${ }^{3}$ \\ ${ }^{122) 3)}$ The Bucharest University of Economic Studies, Romania.
}

\author{
Please cite this article as: \\ Pătărlăgeanu, S.R., Dinu, M. and Constantin, M., \\ 2020. Bibliometric Analysis of the Field of Green \\ Public Procuremen. Amfiteatru Economic, 22(53), \\ pp. 71-81.
}

\section{DOI 10.24818/EA/2019/53/71}

\begin{abstract}
Sustainability and sustainable development are objectives, but also values that must be respected in the field of public procurement. The main objective of this paper is to document the interest in the research area of green public procurement. The research methodology involves the elaboration of a bibliometric analysis (therefore a quantitative research method), in the form of an inventory of the publication activity in the aforementioned field. The analysis was developed by querying the existing database on the Scopus platform, which contains documentation on journals, scientific papers, books and others. The query determined the display of a number of 6,257 scientific documents existing in the database containing the acronym for Green Public Procurement in the title, summary or keywords. The query was conducted on September 25, 2019 and includes publications, regardless of the location or date of publication. The research results confirm the increase of the scientific interest in the field of green public procurement. Since 2010 until the moment of querying the Scopus database, 3,441 documents were identified related to this topic, which represents more than half of the total elaborated documents existing in the database on the same topic, indexed between 1959 and 2009.
\end{abstract}

Keywords: green public procurement, environmental policy, bibliometric analysis, VOSviewer.

JEL Classification: Q57.

* Corresponding author, Simona Roxana Pătărlăgeanu - rpatarlageanu@eam.ase.ro

Vol. $22 \cdot$ No. $53 \cdot$ February 2020 


\section{Introduction}

The European Union is pursuing the greening of public procurement, which is part of the document "EUROPE 2020-A European strategy for smart, environmentally friendly and inclusive growth". It provides directions to be followed to ensure the sustainable development of all Community states. The ecological policy is one of the priorities at Union level and special attention is paid to the elaboration of any document or project with economic or social implications.

The European Commission defines the process of green public procurement as a progressive process, which involves several stages, such as: examining the products or services (from the perspective of the impact on the environment), correctly identifying the needs and expressing them as fully as possible, drawing up clear and accurate technical specifications, as well as establishing the selection criteria.

Green public procurement is considered by the Commission of the European Union to be a vehicle for economic development. This field is of scientific interest due to all the ramifications involved. From the cost perspective: do the environmental alternatives have the same impact on the budget as the other alternatives and if not, what is the additional cost that an economic agent is willing to pay to obtain environmental benefits? From the perspective of the availability of ecological alternatives: for how many of the products and services existing in the market is there an offer? From the perspective of visibility: how can the information regarding the practice of an ecological policy through green public procurement be disseminated? From the perspective of management: how will the existing contracts be negotiated with the current producers and distributors of standard goods and how will the integration of those who practice green technologies be possible?

The main objective of the present paper is to determine the interest in the scientific research area on the field of ecological public procurement and to explain its evolution, starting from the moment of the first scientific document published in the field. In order to achieve such an objective, the quantitative bibliometric analysis is used. Thus, a quantitative research method has been carried out, involving the use of a specialized software product in the field of bibliometric, VOSviewer. The data on which the bibliometric analysis was performed were extracted from the Scopus platform, and then integrated and processed in VOSviewer (version 1.16.13).

The motivation of elaborating the present paper comes from several directions. The implementation of the green public procurement policy is one of the necessary measures to ensure the efficient use of resources, according to the Action Plan for the Circular Economy, adopted in December 2015 (European Commission, 2016). One cannot deny the importance of the field of green public procurement, but has the scientific interest for this field been shown with the same intensity over time? Thus, in this paper, the evolution of the interest in the field of green public procurement is the main issue addressed. The interest has grown steadily, starting with 1959, until 2010-2020, when the number of scientific publications identified in the Scopus database was almost triple compared to that of the publications indexed during the 2000-2009 timeframe, regardless of the country of publication.

Research findings have highlighted the fact that in the United States of America and China there is a strong interest in research in the field of green public procurement. At the same time, interest was also noted in other countries, such as Germany, Japan, the UK, France and Canada. Unfortunately, in the case of Romania, only 18 publications have been identified on the topic of green public procurement. 


\section{Review of the Scientific Literature}

Every year, the public authorities within the European Union spend an estimated $16 \%$ of the Union's Gross National Product on procurement such as: construction components, transport vehicles, office equipment and other goods or services (European Commission, 2008). With this in mind, one can notice the influence that public procurement exerts on the demand for the aforementioned goods. Insofar as there is a considerable demand for ecological or environmentally friendly goods from the public sector, this economic phenomenon with ecological implications will lead to the expansion of the markets for products and services aimed at protecting the natural capital and, at the same time, the companies will become competitive when it comes to adopting and developing green technologies. Ecological or green technology is any type of technology that has been designed to prevent or reduce the negative effects of the production process on natural capital. Thus, public green procurement encourages the use of green technologies, resulting in a reduction of environmental damage (in some cases, it can even prevent it).

According to the "Relief" research project co-funded by the European Commission, if public authorities in the European Union required green electricity, then this choice would have an impact on the $\mathrm{CO}_{2}$ emissions, which would be reduced by 60 million tonnes, meaning $18 \%$ of the EU's commitment to reduce greenhouse gases, according to the Kyoto Protocol. At the same time, if the public authorities opted for green buildings, this would also lead to the reduction of carbon dioxide emissions by 60 million tonnes (European Commission, 2007).

The 20-20-20 energy policy of the European Union aims at achieving several objectives by 2020: $20 \%$ reduction of carbon dioxide emissions, creation of renewable energy in energy mixes by $20 \%$ and $20 \%$ reduction of consumed energy. Thus, the Energy Efficiency Directive (2012/27/EU) supports the practice of environmentally efficient, energy efficient public procurement.

In Romania, there is a project funded under the LIFE Program, the axis "Governance and information", entitled "GPPbest - Best practices exchange and strategic tools for green public procurement", which intends to bring about the improvement of green public procurement policies, in order to meet the sustainable development objectives. Thus, this project supports the Ministry of Environment in implementing the commitments in the field of green public procurement established by Law no. 69/2016, which sets the legislative framework in the field. Several projects with a direct impact on green public procurement have been implemented. For example, the Ministry of the Environment purchased office products, stationery and office equipment in 2017 for 19,800 lei (including VAT). According to the GPPbest pilot actions report in Romania, the technical specifications and criteria for the purchased products were derived from the requirements of the European Union's public procurement procedures.

The specialized literature includes scientific articles, journals, laws, books and other documents that address the issue of green public procurement. This topic is proving to be of global importance, in the context of the orientation towards the circular economy, meant to protect the natural capital. However, the interest in this area has not been manifested at the same intensity over time, but it certainly has shown an evolution. The environmental problems were accentuated, especially starting with the third millennium, which has led to an increased interest in the green public procurement research area.

Vol. $22 \cdot$ No. $53 \cdot$ February 2020 


\section{Research Methodology}

Scientometry is a form of knowledge that aims at measuring the scientific research activity. Bibliometry is a branch of scientometry that focuses mainly on the quantitative study of scientific publications for statistical purposes (Gauthier, 1998). Thus, bibliometry is a research method that involves the elaboration of an inventory of publishing activity at the level of countries or institutions and is used for comparative analyses of productivity in the scientific field. The data can then be used to evaluate the performance of research centres, as a complement to standard evaluation procedures. Also, bibliometric data can represent reference points for science and technology concerns, as longitudinal studies of scientific interests contribute to determining the developing or regressing research areas.

The origins of bibliometrics have proven the need for a quantitative analysis of scientific output, in different forms. Scientometric indicators are also important in the analysis of scientific research (Volovici and Repanovici, 2015).

In order to identify the scientific interest in the field of public green procurement and to determine its evolution, a bibliometric analysis on the works published in the aforementioned field was performed.

The analysis was carried out using the information obtained from querying the existing database on the Scopus platform. The latter contains information on scientific journals, scientific papers, books and more. Through all its scientific resources, Scopus provides users with a database that can be the basis for designing quantitative analyses on research progress in the most diverse fields, including in the field of green public procurement.

In order to elaborate the quantitative analysis of the scientific interest regarding the ecological public procurement, a software product was used, named VOSviewer (version 1.16.13), made by Nees Jan van Eck and Ludo Waltman at the Center of Science and Technological Studies of the Leiden University. VOSviewer allows the analysis of the keywords in the documents existing in the Scopus database, as one of the purposes of this analysis is to highlight the links among the above mentioned keywords.

VOSviewer offers the possibility of creating a map that graphically links the words that appear most frequently in the documents for which the query was performed in the Scopus database. The maps are designed based on the articles, publications, books or citations related to the scientific documents existing in the Scopus database, following the extraction of a file with the extension "ris" from the platform.

The query of the database available on the Scopus platform was performed on September 25, 2019 and had the following code: TITLE-ABS-KEY (GPP). When querying the database, no bibliometric analyses were identified related to green public procurement.

The term "GPP" is an English acronym for the concept of Green Public Procurement, which refers to the process of ecological (or green) public procurement. From a temporal perspective, the query allowed for the results to be displayed regardless of the date when the works were published, provided that the term "GPP" was found in at least the title, summary or keywords of the work existing in the Scopus database at the moment the query was performed. Also, no filters were selected in the query of the database on the affiliation of the authors or on the country where the scientific documents were published. 


\section{Results and discussion}

The Scopus database query revealed 6,257 scientific documents in which the term "GPP" was found at least in their title, summary or keywords. (Table no. 1)

Table no. 1: The number of scientific documents containing the term "GPP" in the title, summary or keywords of the documents existing in the Scopus database, sorted based on the publication timeframe

\begin{tabular}{|c|c|c|}
\hline Timeframe & $\begin{array}{c}\text { Number of existing } \\
\text { scientific documents } \\
\text { in the Scopus data base }\end{array}$ & $\begin{array}{l}\text { The percentage increase of scientific } \\
\text { interest from one period to the next } \\
\text { for studying the subject of „GPP” }\end{array}$ \\
\hline $2010-2020$ & 3,441 & $186.99 \%$ \\
\hline $2000-2009$ & 1,199 & $65.61 \%$ \\
\hline 1990-1999 & 724 & $1.69 \%$ \\
\hline 1980-1989 & 712 & $297.77 \%$ \\
\hline $1970-1979$ & 179 & $5866.67 \%$ \\
\hline 1959-1969 & 3 & - \\
\hline Total & 6.257 & - \\
\hline
\end{tabular}

According to Table no. 1, in the 1959-1969 and 1970-1979 timeframes, only 182 scientific documents were published related to "GPP". This indicates that green public procurement policy was not a concern until the early '80s. However, this changed in the 1980-1989 timeframe, when 712 scientific documents on the same topic were published, which represents an increase of almost 300\%. This indicates the enhanced of interest in the research area of ecological public procurement, which continued throughout 1990-1999, when $1.69 \%$ more scientific documents were published than in the previous timeframe.

Another significant increase in the research interest regarding "GPP" can be noticed in the 2000-2009 timeframe, when 1,199 scientific documents were published (65.61\% more than in the previous period). The peak was reached in the 2010-2020 timeframe, when more than twice as many documents were published than in the previous decade (2000-2009), the increase being of $186.99 \%$. (Figure no. 1)

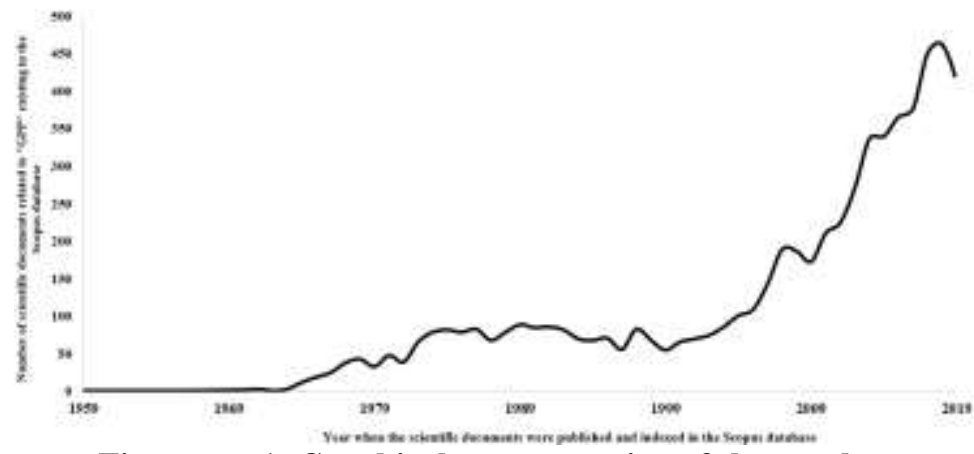

Figure no. 1: Graphical representation of the number of scientific publications, sorted by year

Source: Authors' conceptualization based on the information extracted from the Scopus database 
The United States of America, China and Germany account for 62.66\% (3,921 scientific documents) of the countries contributing to the research and development of ecological / green public procurement. Among the countries with a considerable contribution to this research area are the following: Japan, the United Kingdom, France, Canada, Italy, Australia and Spain. Romania has brought its contribution to the topic of green public procurement by means of 18 publications $(0.28 \%$ of the total occurrences $)$ in the specialized documents identified when querying the Scopus database. Thus, the concern for green public procurement policy exists globally, as evidenced by the research findings of authors from all academic areas. Sabin Stoica (Scopus author ID: 7006359595, affiliation: "Horia Hulubei" National Institute for Research and Development for Nuclear Physics and Engineering) is one of the Romanian authors who wrote the most scientific papers on the aforementioned topic. (Figure no. 2)

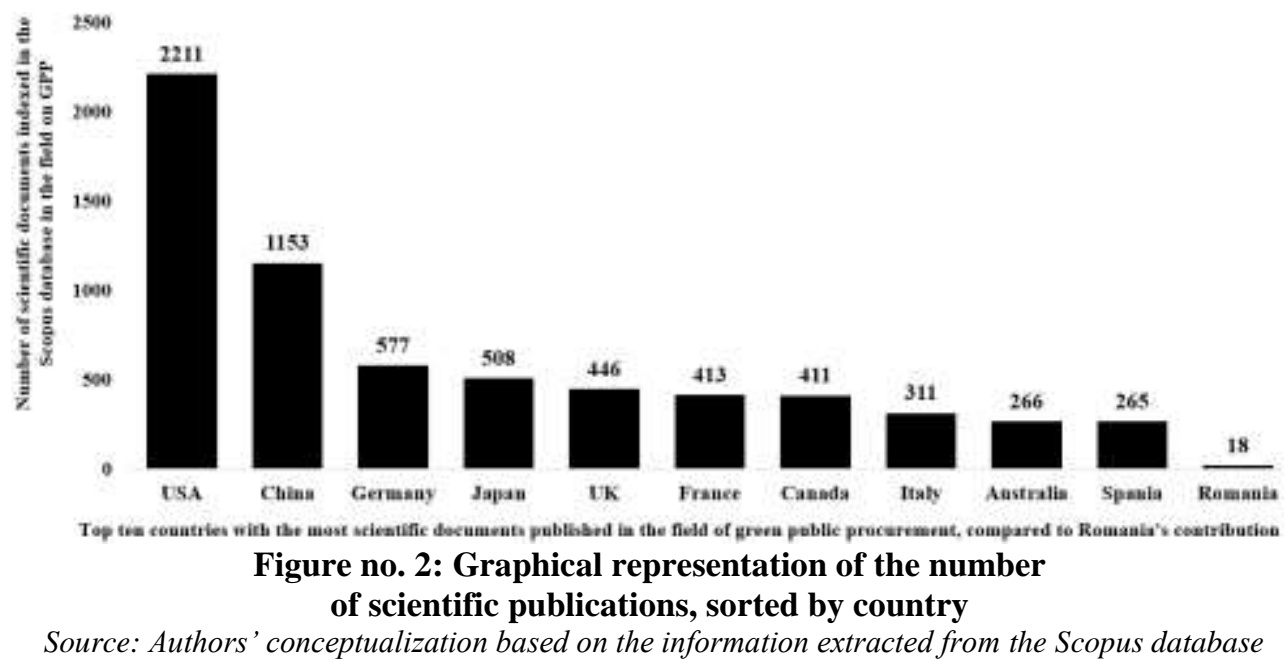

The quantitative bibliometric analysis also involves studying the situation of the cooperation among authors from different countries, regarding the subject of green public procurement. In order to be able to interpret the data, the map generated by the VOSviewer software was used. It was designed based on the following criteria:

- Unit of analysis: Authors.

- Counting method: Full counting.

- Scientific documents with authors from more than 25 countries have been ignored when generating the map.

- Minimum number of scientific documents required for a country to appear on the map: ten.

According to Figure no. 3, certain scientific documents were published by Romanian researchers in cooperation with peers from countries such as Germany, France, Spain, United States of America and others. The purpose of the collaboration is to develop studies and documents that would prove information, answers and solutions regarding the ecological / green public procurement policy. 


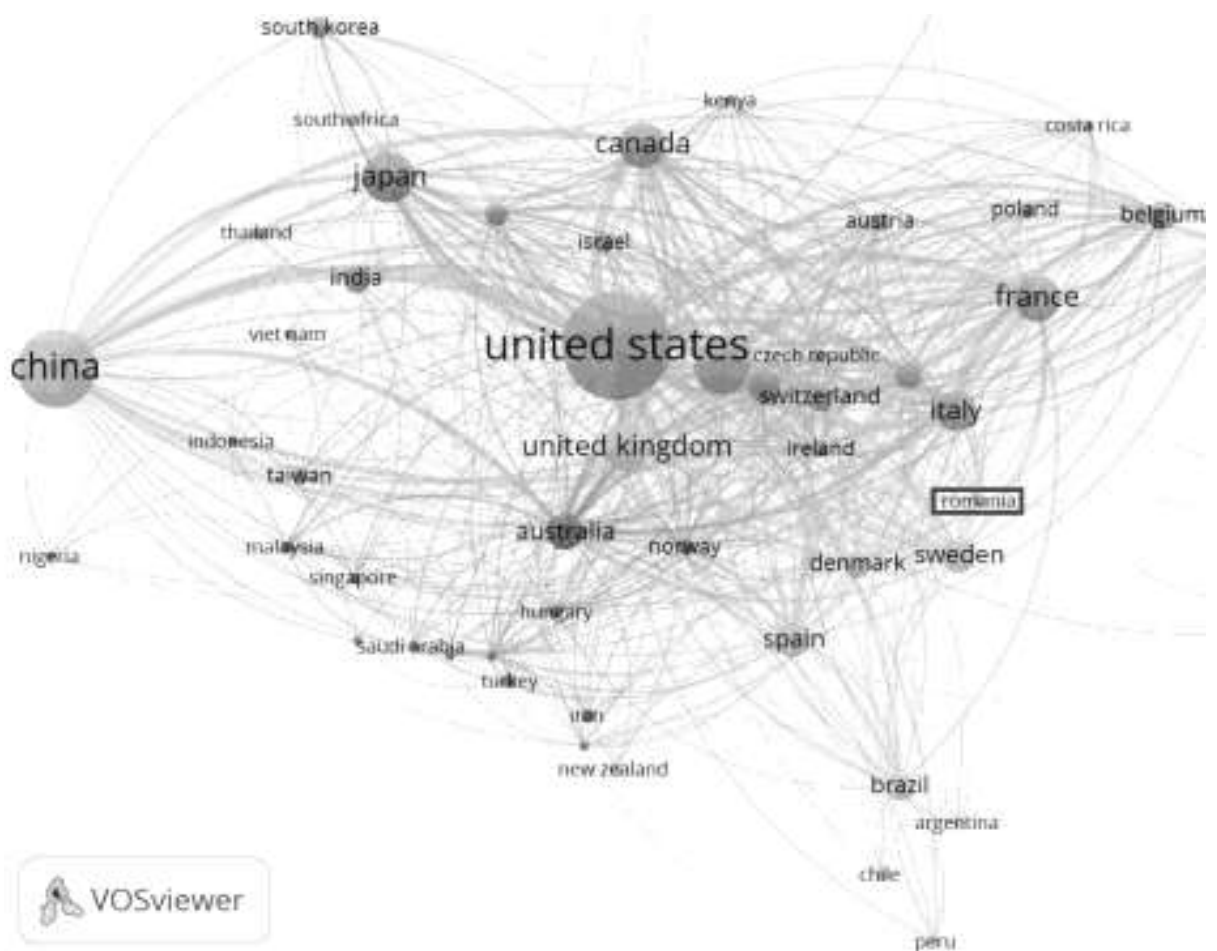

Figure no. 3: The link between scientific documents written on the "GPP" subjects by Romanian authors and other foreign authors

Source: Map generated in VOSviewer, based on the data available in the Scopus database

Since green procurement is a matter of concern for the whole planet and not just for a single country or continent, it is normal to have collaboration in this area of research among professionals from as many scientific centres as possible (Betiol et al., 2015). The strategies targeting green public procurement are complex and need to be aligned with the demands and needs of the private environment (there must be a global vision of the entire system), which is why research plays an important role. Collaboration between researchers from different countries or even continents is essential in this case, because each nation has its own specificity, encompassing different values and principles. Therefore, the same problem faced by multiple countries, such as the conservation of natural capital, can be effectively addressed from multiple perspectives, since such a mix can bring convergent results towards a future where sustainability is a shared value.

Moreover, the quantitative bibliometric analysis involves studying the situation of the collaboration among the authors interested in the topic of green public procurement. The data extracted from the Scopus database were integrated into VOSviewer, where the map in Figure no. 4 was designed, based on the following criteria:

- Unit of analysis: Authors

- Counting method: Full counting

- Scientific documents with more than 25 authors have been ignored when generating the map. 
- In order to be displayed on the map, an author must have written or contributed to at least ten scientific documents (out of 16,475 identified authors, only 310 meet this criteria meaning $1.88 \%$ of the total)

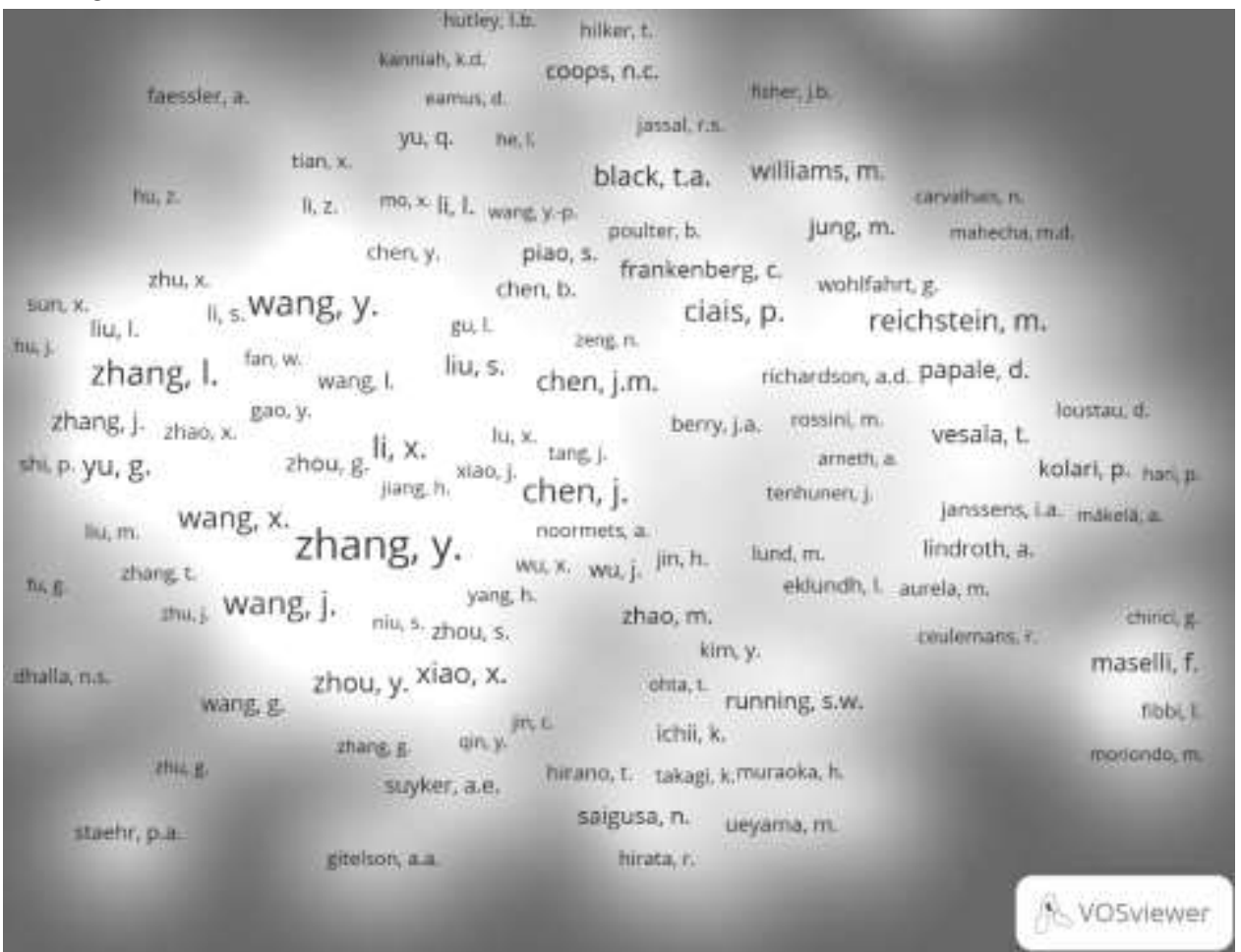

Figure no. 4: Graphical representation of the density of authors who contributed with scientific documents written on the subject of green public procurement Source: Map generated in VOSviewer, based on the data available in the Scopus database

Ciais Philippe (Scopus Author ID: 55399842300), Laboratoire des Sciences du Climat et de l'Environnement affiliate, Gif-sur-Yvette, France, is the author with the most published documents concerning GPP (63 publications), followed by Yu Guirui (Scopus Author ID: 55807480400), an affiliate of the Institute of Geographic Sciences and Natural Resources Research Chinese Academy of Sciences, Beijing, China, who has written 49 publications on green public procurement. Also, Reichstein Markus (Scopus Author ID: 57206534330) is the author of 48 other publications on the same topic, its affiliation being Max Planck Institut für Biogeochemie Jena, Jena, Germany.

Finally, the quantitative bibliometric analysis involves making a density map of the keywords that can be found in the 6,257 scientific documents on green public procurement. The keywords extracted from the Scopus database were integrated into VOSviewer, where the map from Figure no. 5 was generated, which involved selecting a minimum limit of 50 occurrences of a word. This led to an estimate of 630 terms (representing $0.53 \%$ of the total) that fulfil the above mentioned condition (the total number of terms identified at the time of querying the Scopus database being 118,476). 


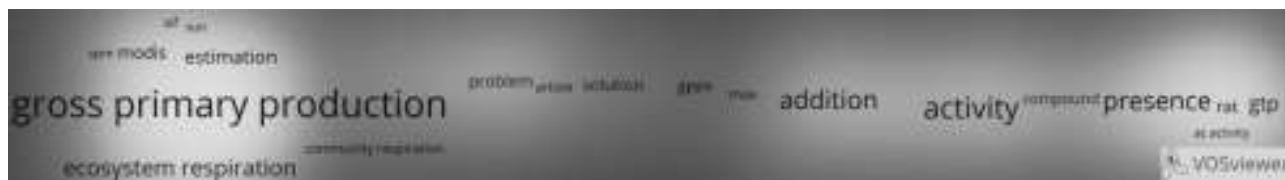

Figure no. 5: The density of the keywords related to green public procurement found in the analysed scientific documents

Source: Map generated in VOSviewer, based on the data available in the Scopus database

Regarding Figure no. 5, the keywords that have fulfilled the above mentioned condition are displayed on the map. Words or word structures of particular importance for the subject of green public procurement within the analyzed publications are the following: "gross primary production", "ecosystem respiration", "estimation", "gtp", "activity".

\section{Conclusions}

Environmental protection, sustainable development, promotion of the circular economy and the efficient use of resources are just some of the values and objectives of the European Union, which Romania has acquired as well. Law no. 69/2016 regarding green public procurement aims to contribute to achieving these objectives.

Because the scientometric indicators are important in the analysis of the scientific research, this paper involved the elaboration of a bibliometric analysis (quantitative research method), using the information obtained from querying the existing database on the Scopus platform. The data has been integrated and processed in the VOSviewer software product, which has led to obtaining the following research results:

- The interest in the research area of green public procurement has almost tripled in the 2010-2020 timeframe (3,441 publications), compared to the 2000-2009 timeframe, when 1,199 documents on this topic were published. The interest in the subject of green public procurement existed before the year 2000 (proof being the 1,618 documents published until 2000), but it did not manifest with the same intensity as at the beginning of the third millennium.

- The country with the most scientific documents published in the field of green public procurement is the USA $(2,211$ articles $-35.33 \%$ of the total). This is followed by China and Germany (1,153 scientific documents and 577 respectively). Romania contributed to addressing the issue of green public procurement through the 18 existing publications in the Scopus database, at the time when the query was performed.

- Ciais Philippe, Yu Guirui and Reichstein Markus are the three authors who published the most scientific documents in the field of green public procurement.

- The words or word structures that have been identified most frequently in scientific documents related to "GPP" are the following: "gross primary production", "ecosystem respiration", "estimation", "gtp", "activity".

The limits of this research coincide with the limits of quantitative bibliometric research. In this case, it is recommended to develop an analysis on the quality and scientific impact of publications, including those related to green public procurement. This analysis should be developed on a series of specific indicators. 
Therefore, the importance of green public procurement was explained in this paper, highlighting its role towards achieving sustainable development. Moreover, the state of scientific knowledge in the field of green public procurement was studied. Regarding directions for future research: in order to have a broader perspective on green public procurement, the authors propose that its impact should be correlated with that of private green procurement on the green products and services market.

\section{References}

Betiol, L.S., Uehara, T.H.K., Laloe, F.K., Appugliese, G.A., Adeodato, S., Ramos, L. and Neto, M.P.M., 2015. Sustainable procurement: The power of public and private consumption for an inclusive green economy. Sao Paulo: Public Administration and Citizenship Program

Cazan, R., 2014. Achiziţii publice ecologice în România. Protecţia Mediului prin cheltuieli publice responsabile. [pdf] Available at: <https://www.ecopolis.org.ro/media/Achizitii $\%$ 20publice\%20ecologice\%20in\%20romania-final.pdf $>$ [Accessed 27 September 2019].

European Commission, 2007. Achiziții ecologice - Ghidul achiziţiilor publice ecologice. Luxemburg: Oficiul pentru Publicaţii Oficiale ale Comunităţilor Europene. [online] Available at: <https://ec.europa.eu/environment/archives/gpp/buying_green_handbook_ ro.pdf $>$ [Accessed 27 September 2019].

European Commission, 2008. Achiziții publice pentru îmbunătățirea condițiilor de mediu. [online] Available at: <https://eur-lex.europa.eu/legal-content/RO/TXT/HTML/?uri= CELEX:52008DC0400\&from=EN> [Accessed 26 September 2019].

European Commission, 2010. EUROPA 2020 O strategie europeană pentru o creștere inteligentă, ecologică și favorabilă incluziunii. [online] Available at: <https://eurlex.europa.eu/legal-content/RO/TXT/HTML/?uri=CELEX:52010DC2020\&from=RO> [Accessed 28 September 2019]

European Commission, 2016. Buying green! A handbook on green public procurement 3rd Edition. Luxembourg: Publications Office of the European Union. [pdf] Available at: <https://ec.europa.eu/environment/gpp/pdf/Buying-Green-Handbook-3rd-Edition.pdf> [Accessed 28 September 2019].

European Commission, 2016. Green Public Procurement. A Guild for NGOs. [online] Available at: <http://www.sustainable-procurement.org/ngonetwork/> [Accessed 29 September 2019].

European Commission, 2017. The role of waste-to-energy in the circular economy. [pdf] Available at: 〈https://ec.europa.eu/environment/waste/waste-to-energy.pdf> [Accessed 28 September 2019].

Eurostat, 2015. Smarter, greener, more inclusive? Indicators to support the Europe 2020 strategy. Luxemburg: Publications Office of the Eruopean Union [online] Available at: <https://ec.europa.eu/eurostat/statistics.explained/index.php/Smarter,_greener,_more_in clusive_indicators_to_support_the_Europe_2020_strategy/> [Accessed 29 September 2019]. 
Fondazione Ecosistemi, 2018. GPPbest Best practices exchange and strategic tools for GPP. [online] Available at: <https://www.gppbest.eu/?page_id=25\&lang=ro> [Accessed 28 September 2019].

Fondazione Ecosistemi, 2018. Raportul acţiunii pilot GPPbest în România. [online] Available at: <https://www.gppbest.eu/?p=621\&lang=ro> [Accessed 28 September 2019].

Gauthier, É., 1998. Bibliometric Analysis of Scientific and Technological Research: A User's Guild to the Methodology. [online] Available at: <http://www.publications.gc.ca/ Collection/Statcan/88F0006X/88F0006XIE1998008.pdf $>$ [Accessed 26 September 2019].

SEVEn - The Energy Efficiency Center, 2012. Achiziţii şi Protecţia Mediului. Ghid de achiziţie a vehiculelor utilizând criterii de eficienţă energetică şi ecologică. [online] Available at: <https://www.anre.ro> [Accessed 28 September 2019].

Temmerman, L. and Habets, A., 2013. Green Public Procurement: Analysis of current practices and possible future developments. [pdf] Available at: <https://www.maastrichtuniversity.nl/sites/default/files/2013/habets.pdf> [Accessed 27 September 2019].

Van Eck, N.J. and Waltman, L., 2011. Text mining and visualization using VOSviewer. [online] Available at: <https://arxiv.org/ftp/arxiv/papers/1109/1109.2058.pdf> [Accessed 29 September 2019].

Van Eck, N.J. and Waltman, L., 2019. VOSviewer Manual for version 1.6.13. [online] Available at: <https://www.vosviewer.com/getting-started\#vosviewer-manual> [Accessed 26 September 2019].

Volovici, R-M. and Repanovici, A., 2015. Analiza cercetării ştiinţifice prin indicatori scientometrici. Asociaţia bibliotecarilor din România [online] Available at: <https://www.ceeol.com/search/article-detail?id=585177> [Accessed 28 September 2019].

Waltman, L., and Noyons, E., 2018. Bibliometrics for Research Management and Research Evaluation. [online] Available at: 〈https://www.cwts.nl/pdf/CWTS_bibliometrics.pdf> [Accessed 29 September 2019]. 